\title{
Social Anxiety in Japanese Learners: Implications for English Education
}

\section{David Ostman}

\section{Kumamoto Gakuen University}

\section{Larry Xethakis}

Sojo University

\section{Reference Data}

Ostman, D., \& Xethakis, L. (2021). Social anxiety in Japanese learners: Implications for English education. In P. Clements, R. Derrah, \& P. Ferguson (Eds.), Communities of teachers \& learners. Tokyo: JALT. https://doi.org/10.37546/JALTPCP2020-19

The role of affect in language learning remains an under-examined area of inquiry. While research into foreign language anxiety has progressed, as more interaction-focused methodologies are employed in the classroom the influence of social anxiety on learners' attitudes towards language learning should receive more attention. The current study adopted an explanatory sequential design to examine feelings of social anxiety among first-year university students $(n=810)$ at a private university in Western Japan enrolled in an oral communication course heavily emphasizing student interaction. Survey data revealed a significant decrease in anxiety, and corpus analysis of student responses revealed the importance of learners' familiarity with classmates in reducing feelings of unease. These results suggest that social dimensions play an important role in helping learners cope with interactional anxiety. They also suggest that strategies for reducing social anxiety should be a focus of further inquiry.

言語学習における情意の役割は、まだ十分に研究されていない分野である。外国語不安に関する研究は進んできてはい るが、教室でのやりとりに焦点をあわせた方法論が多く採用されるにつれ、社会不安が学習者の言語学習態度に与える影響 によりいっそう注目すべきと考える。本研究では、西日本の私立大学において、学生との対話を重視したオーラルコミユ二ケー ションコースに在籍する大学 1 年生 $(n=810)$ を対象に、説明的順次デザインを用いて学生の社会不安感を調査した。結果とし て、不安感は顕著に減少し、学生の回答をコーパス分析したところ、不安感の減少にはクラスメートとの親密さが重要であるこ とが明らかになった。これらの結果は、学習者が社交不安に対処する上で、社会的側面が重要な役割を果たしていることを示 している。加えて社会不安を軽減するための方略が、今後の研究の焦点となるべきであることも示唆している。
7 ith a few exceptions, the impact of learners' affective states on the language learning process has been a neglected topic in the field of applied linguistics (MacIntyre \& Vincze, 2017). This has been due in part to the primary concern of language acquisition research with learner cognition and language development (Swain, 2013). However, as Swain points out, "Emotions are socially and culturally derived and, along with cognition, they mediate learning" ( $p$.196). One such emotion is social anxiety, which has been indicated as crucial in mediating language-learning outcomes (e.g., King \& Smith, 2017; Zhou, 2016).

Up to now, one of the primary concerns with regards to anxiety in the EFL context has been the anxiety associated with actually communicating in a foreign language; however, as group-based learning approaches continue to see increased adoption in language learning classrooms (Mitchell, 2017), attention also needs to be given to the role that anxiety plays in students' attitudes toward language learning, an area in which research is lacking (Dykes, 2017; Zhou, 2016). This study attempts to address this need by investigating feelings of social anxiety in Japanese university students enrolled in an oral communication course heavily emphasizing student interaction and communication.

\section{Literature Review}

Social anxiety - a feeling of unease or apprehension at being observed and evaluated by others in social interactions-includes a number of commonly experienced forms of anxiety, including shyness, communication apprehension, speech anxiety and audience anxiety (Leary, 1983). Woodrow (2006) reported that two aspects of social anxiety-oral performance and social communication-were among the most reported sources of anxiety for language learners, and further that the Japanese learners in her study tended to exhibit more anxiety than learners from other cultures. Not surprisingly, in a largescale study of Japanese university students, $75 \%$ (792 of 1,057) expressed feeling selfconscious when speaking in front of others (Burden, 2002). 
Given the nature of the language classroom in Japan, described by King and Smith (2017) as "a highly public social performance situation in which one's behaviour and utterances are open to the scrutiny of others" (p. 99), feelings of social anxiousness may be particularly relevant for Japanese learners of English. King and Smith portray the language classroom as a place where learners feel as if they are being observed and judged by other learners leading to a disproportionate concern with producing grammaticallycorrect English and comprehensible pronunciation, and even whether what they were saying is interesting to others. In such an atmosphere of heightened anxiety, learner hesitance and resistance to the prospect of speaking English in front of peers becomes not only understandable, but also a significant pedagogical concern.

The anxiety learners experience when communicating can be debilitating in the moment (Woodrow, 2006), causing them to speak less, interact less frequently, and share less information with others (McCroskey \& Richmond, 1992). In addition, it can also cause learners to adopt behaviors that are detrimental to the language learning process. Hayashi and Cherry (2004), in their study on EFL students' learning preferences, found that even when learners expressed a preference for communicating and expressing themselves in English, they were disinclined to actually speak English in pairs or even with their friends. This "aversion by the subjects to risk taking" (Hayashi \& Cherry, p. 88) echoes previous research which found that learners prefer to avoid failure in front of others, even when this means avoiding success (Miyake \& Yamazaki, 1995, as cited in Brown, 2004), and would appear to be a concrete example of the supposition by Ehrman (1996) that anxious learners favor safer activities, even when this tendency might limit their opportunities for learning.

One group of English learners particularly susceptible to the emotions described above are first-year university students-who often find themselves in an unfamiliar social environment where there may be few peers whom they feel comfortable interacting with. Social anxiety, as has been noted, is most prominent when people are not acquainted with those around them (Zakahi, et al., 1993), to which may be further added the anxiety stemming from an unfamiliar pedagogical environment. As Dykes (2017) indicates, while reforms in English education have encouraged a more communicative approach to language teaching, junior-high and high school English classes remain predominantly teacher-focused and often provide few opportunities for communication. Universitylevel courses, in contrast, tend to emphasize oral communication over knowledge of the language, and interactive over individual learning. When faced with such drastic differences in learning styles and environments, learners may experience feelings of unease (Matsuura, et al., 2001).
The present longitudinal study examines the effects of an interaction and production focused English oral communication curriculum on learner experience of performance anxiety (i.e., public speaking anxiety/speech anxiety) among a cohort of first-year university English learners, and addresses the following questions:

1. What are the effects of an interaction-focused curriculum on learners' experiences of anxiety?

2. What factors may be identified as mediating learners' feelings of unease?

\section{Methodology}

\section{Participants}

The participants $(\mathrm{N}=810)$ in this study comprised a convenience sample of nonEnglish majors attending a private university in Western Japan. All were Japanese first-year students (male=547; female=215; gender not indicated=48), primarily from Kyushu and surrounding areas. The majority were from a range of science related fields: Engineering (35.6\%), Computer and Information Sciences (19.1\%), Pharmaceutical Sciences (19.0\%), Biotechnology and Life Science (18.5\%). On the basis of an internal placement test, the majority of the students corresponded to CEFR levels A2 and B1.

All participants were enrolled in a first-year English communication course. The course is a compulsory English communication course, which meets for two 90-minute classes per week, for 60 times over the course of a year, with approximately 25 to 30 students from different departments in each class. The goal of the course is to improve learners' ability to interact and communicate through repeated interactions with multiple partners in 5 to 10 minute non-rehearsed conversations on topics that are directly relevant to the learner's life (e.g., free-time activities, music, YouTube, favorite places, etc.). The course was introduced into the university's English curriculum as a means to rectify the deficit in communication skills commonly found among lower-level Japanese learners of English, such as those at the authors' universities. The overarching aim of the course is to allow learners to focus on meaningful interactions with their classmates, and for them to come to see English as a tool for authentic communication, rather than a set of rules that must be mastered.

The course is organized in three-class cycles, with each cycle based on a theme or topic. These serve as starting points for learner interaction by providing a framework for the language and interaction skills presented in each unit. The first class of each cycle focuses on building up a collection of words and phrases to help learners talk about the topic through a range of communicative activities. The second class focuses 
on structured speaking practice, as well as introducing conversation strategies, such as asking follow-up questions, clarifying meaning, etc. This allows learners to accumulate a repertoire of questions, answers, and skills for use in subsequent nonrehearsed conversations. In the third class, students repeatedly engage in these nonrehearsed conversations with several different partners. They then record a five-minute conversation with a new partner. Finally, they listen to their conversation, and reflect on what they did well and what they could do better in the future. The course covers between 12 and 16 topics each year, with assessment consisting of four 10-minute speaking tests given at the midpoint and end of each term.

\section{Data Collection Procedures}

This study adopted an explanatory sequential design (Creswell \& Piano-Clark, 2017). In this design, quantitative data is gathered first, and subsequently, qualitative data is collected to help explain the quantitative results. The initial phase of this study focused on collecting and analyzing survey data to determine the effect of the curriculum on participants' feelings of anxiety. The subsequent phase of qualitative data collection employed a follow-up survey to clarify possible sources of the reduction in anxiety found in the quantitative results.

Participation in this study was voluntary, with the first section of the questionnaire described below asking for participants' informed consent and clearly stating in Japanese that those not wishing to participate could do so simply by not submitting the form.

Quantitative data collection took place once at the beginning of the course and again at the end of the first term (during classes 3 and 29 approximately). The survey was administered using the Google Forms online platform. The first section of the form explained the purpose of the survey, procedures for obtaining informed consent, and demographic information including gender and department. The second section of the form comprised a 7-item measure of respondents' feelings of social anxiety in public performance situations, using a 5 -point Likert scale $(1=$ not at all characteristic of $m e$; and 5 = extremely characteristic of $m e$ ). Originally developed by Leary (1983), the 7-item Japanese version of this measure employed in this study was developed by Okabayashi and Seiwa (1992; Appendix A), and evidence for its validity was reported by Xethakis (2020). The reliability of the scale, as measured by Cronbach's alpha, was comparable for both administrations of the survey, .927 and .933 , respectively. All questions were in Japanese.
Qualitative data was gathered at the mid-point of the second term of the course (during class 46 approximately). This survey was administered using the Survey Monkey platform (Appendix B). While first section of the form was identical to that above, the second section comprised one closed-ended item (I feel less anxious talking and interacting with my classmates now than I did at the beginning of the year) to which students responded using a six-point Likert-scale ( $1=$ strongly disagree; $6=$ strongly agree). This was followed with an open-ended question asking students to provide a short reason for their answer in Japanese, with the aim of revealing what aspects of their experience engendered or eased feelings of anxiety.

\section{Quantitative Data}

\section{Results}

Scale means were calculated for the first $(n=609, M=20.83, S D=7.34$ ) and second ( $n=558, M=20.05, S D=7.514$ ) administrations of the anxiety survey. One-sample Kolmorogov-Smirnov tests were used to determine the normality of the scores (i.e., whether or not the distribution of scores on the survey resembled a normal distribution). Results for the first $(Z=1.437, p<.05)$ and the second $(Z=1.488, p<$ $.05)$ administrations revealed significant deviations from normality in both sets of scores. For this reason, non-parametric tests, which do not assume normal distribution, were employed in answering the first research question concerning the effects of an interaction-focused curriculum on learners' experiences of anxiety.

Results from a Wilcoxon signed-rank test showed a significant reduction in anxiety between the first and second administrations of the survey $(Z=-4.68, p<.001)$, with the median score on the anxiety survey declining from first $(M d=21.00)$ to second $(M d$ $=20.00$ ) administration. While the effect size (i.e., the difference between the scores) was rather small $(r=.15)$, this is not surprising considering that there was no direct intervention employed in this study.

Responses to the Likert-scale item on the follow-up survey-I feel less anxious talking and interacting with my classmates now than I did at the beginning of the year-seem to provide further support for this view. On a six-point Likert scale, the mean for this item was $4.63(\mathrm{SD}=1.26)$. Additionally, $412(61.6 \%)$ respondents chose either agree (5) or strongly agree (6), while only 43 chose strongly disagree (1) or disagree (2). This again seems to indicate that a significant majority of learners felt that their feelings of anxiety lessened over the term of the course. 


\section{Qualitative Data}

Qualitative analysis was undertaken to answer the second research question, concerning factors that may have mediated learners' feelings of unease, and to gain insight into factors underlying the observed quantitative changes in learners' perceptions of social anxiety. A total of 669 valid responses to the open-ended question from the follow-up survey were combined to create corpuses, the text of which were analyzed using corpus software AntConc, Version 3.5.8 (Anthony, 2019). This process was undertaken with the assistance of a Japanese native speaker, with whom any English language responses were reverse-translated into Japanese.

Initially, the analysis involved generating a list of terms which frequently occurred in the corpus of learner responses. High-frequency terms were isolated and examined in the sentences in which they appeared. Responses were then coded on the basis of the context in which the terms were used by respondents. The process of coding was carried out independently by both authors, and multiple rounds of coding were employed to ensure reliability (Revesz, 2012)

The results presented below focus primarily categories relating to affect and its reduction to provide further insight as to: 1 ) the manner in which learners employed the terms anxiety/anxiousness and nervous/nervousness; 2 ) what areas learners reported acclimation (i.e., getting used to); 3) prominent mechanisms underlying learner acclimation. The examples presented below were chosen by the authors from among those coded into each category as being representative of the category as a whole, and are not meant to be exhaustive. Examples are designated by an ID number assigned to each response.

\section{Anxiety}

Learners employed terms relating to anxiety a total of 52 times (anxiety/feeling of anxiety, 39; nervous/nervousness, 13). The continuing presence of anxiety was revealed in 14 instances, while the remaining 38 instances indicated the non-presence of anxiety, or the abatement of anxiety. The more frequent occurrence of the latter reflects the overall trend of decreased anxiety.
Table 1

Contexts in Which the Term "Anxiety" Was Employed, Instances, and Examples

\begin{tabular}{lcl}
\hline Category & Instances & \multicolumn{1}{c}{ Example } \\
\hline $\begin{array}{l}\text { Continuing presence of } \\
\text { anxiety }\end{array}$ & 14 & $\begin{array}{l}\text { My feelings of anxiety when talking to others have } \\
\text { not changed. (\#77) }\end{array}$ \\
$\begin{array}{l}\text { Non-presence of anxiety } \\
\text { Abatement of anxiety }\end{array}$ & 12 & $\begin{array}{l}\text { From the beginning I did not feel anxious. (\#19) } \\
\text { Little by little I became able to speak English, so my } \\
\text { anxiety decreased. (\#146) }\end{array}$ \\
\hline
\end{tabular}

\section{"I Got Used to It" - Acclimation}

The phrase get used to (various forms of the verb nareru) appeared with significant frequency in the corpus (118 instances). While 4 learners indicated inability to acclimate, all other instances, 114, indicated positive acclimation related to aspects of the course. While the most frequent responses were brief (e.g., responses 574 and 139 in Table 2), the remaining responses indicated a greater degree of comfort with speaking in English, with classmates, and with the general atmosphere.

Table 2

Contexts in Which the Term "Acclimate" Was Employed, Instances, and Examples

\begin{tabular}{lcl}
\hline Category & Instances & Example \\
\hline Inability to acclimate & $4 \quad \begin{array}{l}\text { Because of nervousness and not being used to } \\
\text { English, I became flustered when interacting with } \\
\text { others. (\#220) }\end{array}$ \\
Positive acclimation & $114 \quad \begin{array}{l}\text { I got used to it. (\#574) } \\
\text { Because I got used to it. (\#139) } \\
\text { Little by little I became able to speak English, so my } \\
\text { anxiety decreased. (\#146) } \\
\text { I got used to my classmates. (\#210) } \\
\text { As I got used to university life, I made friends who I } \\
\text { could talk easily with. (\#90) }\end{array}$ \\
\end{tabular}


As to the mechanisms underscoring learner acclimation, two areas were identified: 1) increased interactional opportunities, and 2) improved interpersonal interactions.

Increased Interactional Opportunities

Learner response analysis revealed 54 instances of terms related to course opportunities (opportunity/opportunities; chances). From this total, 52 indicated learner belief that the course afforded increased communication opportunities, while remaining responses indicated learner belief that course curriculum facilitated opportunities for interpersonal interactions. Furthermore, learners encouraged through the curriculum to engage in peer-to-peer conversations reported that the increased communicative interactions were enjoyable, as evidenced in the frequency of the words fun/enjoyable, e.g., There were many activities for pairs and groups of four, so it was enjoyable (\#364); We could communicate enjoyably using a wide vocabulary (\#401)

Table 3

Contexts Indicating an Increase in Interactional Activities, Instances, and Examples

\begin{tabular}{lcl}
\hline Category & Instances & \multicolumn{1}{c}{ Example } \\
\hline $\begin{array}{l}\text { Learner belief that the course } \\
\text { afforded increased communication }\end{array}$ & 52 & $\begin{array}{l}\text { Through English class, opportunities } \\
\text { to speak increased. (\#617) } \\
\text { opportunities }\end{array}$ \\
$\begin{array}{l}\text { There were many opportunities to } \\
\text { speak. }(\# 571)\end{array}$ \\
$\begin{array}{l}\text { Learner belief that course } \\
\text { curriculum facilitated } \\
\text { opportunities for interpersonal } \\
\text { interactions }\end{array}$ & 2 & $\begin{array}{l}\text { During the class, there were } \\
\text { opportunities to interact with } \\
\text { classmates. (\#508) }\end{array}$ \\
\hline
\end{tabular}

\section{Improved Interpersonal Interactions}

With the exception of one learner who reported continued interpersonal anxiety, I am from out of prefecture, and just as when I entered my faculty I didn't have any friends (\#26) 122 of 123 instances of terms related to interpersonal interaction (classmate; friend; partner, etc.) were employed to indicate the growth of interpersonal relationships visà-vis the EFL curriculum. This observation correlates with the high co-incidence (45 instances) of the term nakayoku (to get along with; to make friends with; to grow closer), e.g., I became friends with classmates; (\#93), as well as the verbal phrase get used to, e.g., In the beginning I felt resistance to speaking in English, but I gradually got used to it and I think I grew closer to my classmates (\#271).

To help reveal the underlying bases for these improved relationships, responses were further classified into the following five categories: 1) formation of new friendships, growing closer, or getting to know others; 2 ) increased opportunities to converse or interact with others; 3 ) positive influence due to other learners' kindness, consideration or engagement (1); 4) acclimation to interaction or speaking with others; and 5) positive curricular considerations. Table 4 presents these categories, the number of instances and representative examples from each category.

These results suggest that while increased opportunities to engage in conversation amongst peers were perceived as contributing to reductions in feelings of unease, the presence of interpersonal interactions with friends and the act of forming new friendships were indicated as a more significant factor in this decrease. This understanding of the data is further reinforced by learner responses indicating that the kindness of friends-rather than factors intrinsic to the course curriculumwere mechanisms for anxiety reduction. Indeed, learner belief in the importance of curriculum-related reductions in anxiety (categories 2, 4, and 5) were indicated with less frequency than that attributed to the actions of friends, and the act of forming friendships (categories 1 and 3).

Table 4

Subcategories Indicating Improved Interpersonal Interaction, Instances, and Examples

\begin{tabular}{|c|c|c|}
\hline Category & Instances & Example \\
\hline \multirow{2}{*}{$\begin{array}{l}\text { Formation of new } \\
\text { friendships, growing } \\
\text { closer, getting to know } \\
\text { others }\end{array}$} & \multirow[t]{2}{*}{48} & $\begin{array}{l}\text { Speaking repeatedly in English with classmates } \\
\text { during class, we learned more about each other. } \\
(\# 233)\end{array}$ \\
\hline & & $\begin{array}{l}\text { I gradually memorized everyone's name and face, } \\
\text { and became able to speak with them. (\#620) }\end{array}$ \\
\hline \multirow{2}{*}{$\begin{array}{l}\text { Increased opportunities } \\
\text { to converse, interact } \\
\text { with others }\end{array}$} & \multirow[t]{2}{*}{17} & $\begin{array}{l}\text { I was able to smoothly converse with classmates } \\
\text { that I don't usually talk with. }(\# 453)\end{array}$ \\
\hline & & $\begin{array}{l}\text { As time went on, opportunities to interact with } \\
\text { classmates increased. }(\# 660)\end{array}$ \\
\hline
\end{tabular}




\section{Category}

Instances

Positive influence due to kindness, consideration, engagement of others

Acclimation to interaction, speaking with others

Positive curricular considerations
Example

All of my classmates were very kind and easy to talk with. (\#543)

When I had difficulties, my classmates helped me through it, and listened patiently until I could answer them, so my anxiety decreased. (\#169)

There was a lot of time for talking, so I could get used to talking in English with my friends. (\#266)

I became able to talk with everyone. (\#661)

The class progression was interesting, and I became able to talk with my classmates. (\#211) There were many opportunities to practice with my friends. (\#332)

We were able to immediately put into practice the things we learned in class, which made things easy to memorize and fun to study. (\#219)

\section{Discussion}

Social anxiety has been variously connected with L2 learning (e.g., lizuka, 2010; King \& Smith, 2017; Zhou, 2016). In developing an anxiety scale for L2 learners (Foreign Language Classroom Anxiety Scale), Horwitz, et al., (1986) incorporated three components, one of which relates to anxiety stemming from interpersonal interactions: fear of negative evaluation. Similarly, Leary and Kowalski (1997) indicated L2 anxiety as partially originating from learner perception of being evaluated by peers. According to lizuka (2010), such interpersonal evaluation anxiety results from learners' increased motivation to make a desired impression and may be exacerbated by a lack of learner confidence in their ability to generate such an impression.

In the context of the language classroom, interpersonal evaluation anxiety may be understood as one of a number of personal and interpersonal anxieties, which Young (1991) lists as "speech anxiety, shyness, stage fright, embarrassment, social-evaluative anxiety, and communication apprehension" (p. 427). Taken together, such learner anxieties present potential challenges to educators attempting to implement oralcommunication-based curricula.
In the present study, corpus-based analysis of learner responses regarding perceptions of social anxiety revealed several areas of interest to the ESL/EFL educator. While repeated oral activities in pairs and small groups would appear to correlate with reductions in student anxiety, this interpretation ignores interpersonal factors that may be equally-if not more-important than repeated engagement in communicative activities. This research indicates that the relationship between foreign-language oral practice and learner anxiety may require further consideration.

Learner responses frequently connected the easing of anxiety with acclimation to classmates, as well as the importance of others' evidencing helping attitudes and behaviors during communication, stressing the importance (to learners) of forming bonds of friendship and trust with others. While curricular factors were also indicated as responsible for alleviating perceived stress, these results highlight the importance of interpersonal considerations when attempting to implement an oral-communicationcentered curriculum.

While anxiety specific to L2 language learning deserves continued attention and investigation, the present research suggests that rather than the task of communication itself, the social environment in which communication transpires is a critical component underlying the alleviating (or exacerbating) of social anxiety. Stated simply, students who believed that social bonds with communication partners had strengthened, reported reductions in anxiety. Conversely, in some cases students who failed to establish ties of friendship with classmates did not perceive a lessening of anxiety.

This sheds light on the functioning of social anxiety amongst foreign-language learners. While providing ESL/EFL students with increased opportunities to communicate may result in increased comfort with the language, a consideration of interpersonal variables is critical if social anxiety-an impediment to communicative development-is to be addressed. Reis et al. (2010) argues that the exchange of positive personal events serves to forge friendships, and boost self-esteem through positive feedback from interlocutors. Furthermore, positive responses from listeners act to enhance feelings of an event, once shared. Encouraging learners to exchange personal information through $\mathrm{L} 2$ communicative activities represents one strategy for combating learner social anxiety.

Addressing learner social anxiety may also serve to expedite communicative performance. Ehrman and Dörnyei (1998) note that for learners to openly express personal ideas and opinions, they must first gain confidence that they will not be rejected by peers. Dörnyei and Murphey (2003) further argue that low-risk, self-disclosure activities (i.e., information exchanges in pairs/small groups) are efficacious in promoting 
acceptance amongst peers. Addressing L2 social anxiety may further serve to build a sense of community amongst learners, which Dykes (2017) indicates as a possible factor in reducing foreign-language anxiety. Furthermore, he hypothesizes that learner anxiety will be reduced in a learning environment "designed to offer small group support and extensive opportunities for lightly monitored peer to peer communication” (p. 38). The present research would appear to offer credibility to such a curricular approach.

As the learners in this research were first-year non-English undergraduates, significant time was spent engaging students in exercises that, while minimally challenging, facilitated familiarity with classmates. In this way, early efforts to encourage the establishment of such ties may have contributed to the creation of a learning environment in which learners perceived reduced evaluation from peers, and a greater degree of closeness through the repeated sharing of personal information in decentralized, small-scale communicative activities. It is possible that reductions in anxiety through the strengthening of interpersonal relationships are a pre-requisite for some degree of overall communicative development. Future research should endeavor to identify specific interpersonal factors efficacious in contributing to reduced social anxiety.

\section{Conclusion}

Quantitative data from a validated survey instrument measuring social anxiety among first-year students at a Japanese university, together with qualitative data in the form of student responses to an open-ended question were employed to answer this study's two research questions concerning the effects of an interaction-focused curriculum on perceptions of anxiety and the factors that mediated learners' feelings of unease. Statistical analyses of learners' scores showed a small but significant decline in anxiety over the term of the course. Corpus analysis of student responses carried out to identify factors underlying the decrease in anxiety revealed that learners' sense of familiarity with classmates (or lack thereof) was an important factor in mediating perceptions of social anxiety. The results add evidence to the view that communicating in $\mathrm{L} 2$ is not just a matter of knowledge of language; it has a strong social dimension as well. Researchbased strategies to reduce social anxiety should be a focus of further inquiry.

\section{Bio Data}

David Ostman teaches in the Foreign Languages Department at Kumamoto Gakuen University. His primary research involves the use of short, narrative fiction to facilitate intercultural understanding. Recent work involves the utilization of flash fiction and immigrant biography to aid learner engagement in empathic perspective-taking from the standpoint of other cultures .

Larry Xethakis teaches in the Sojo International Learning Center at Sojo University. His primary research interests include psychological, cognitive and social factors influencing learner performance in group-based learning approaches, as well as the development of communities of practice among collaborating teachers.

\section{References}

Anthony, L. (2019). AntConc (Version 3.5.8) [Computer Software]. Tokyo, Japan: Waseda University. Retrieved March 26, 2020 from https://www.laurenceanthony.net/software Brown, R. A. (2004). The effects of social anxiety on English language learning in Japan. Information and Communication Studies, 30, 7-11. Retrieved March 26, 2020 from https:// bunkyo.repo.nii.ac.jp/?action=repository_uri\&item_id=3060\&file_id=37\&file_no=1

Burden, P. (2002). A cross sectional study of attitudes and manifestations of apathy of university students towards studying English. The Language Teacher, 26(3), 3-10. Retrieved March 26, 2020 from http://jalt-publications.org/old_tlt/articles/2002/03/burden

Creswell, J. W., \& Piano Clark, V. L. (2017). Designing and conducting mixed methods research. Thousand Oaks, CA: Sage.

Dörnyei, Z., \& Murphey, T. (2003). Group dynamics in the language classroom. Cambridge, UK: Cambridge University Press.

Dykes, R. (2017). The effect of communicative based teaching on foreign language anxiety. International Education and Exchange Research, 1, 37-49. Retrieved March 26, 2020 from https:// www.u-fukui.ac.jp/wp/wp-content/uploads/4_DYKES.pdf

Ehrman, M. (1996). An exploration of adult language learner motivation, self-efficacy, and anxiety. In R. Oxford (Ed.), Language learning motivation: Pathways to the new century (pp. 81-104). Honolulu, HI: University of Hawaii Press.

Ehrman, M. E., \& Dörnyei, Z. (1998). Interpersonal dynamics in second language education: The visible and invisible classroom. Thousand Oaks, CA: Sage.

Hayashi, M., \& Cherry, D. (2004). Japanese students' learning style preferences in the EFL classroom. Bulletin of Hokuriku University, 28, 83-93. Retrieved March 26, 2020 from https:// www.hokuriku-u.ac.jp/about/campus/libraryDATA/kiyo28/mirai3.pdf 


\section{JALT2020}

COMMUNITIES OF
TEACHERS \& IEARNERS
Horwitz, E. K., Horwitz, M. B., \& Cope, J. (1986). Foreign language classroom anxiety. The Modern Language Journal, 70(2), 125-132.

lizuka, K. (2010). Second language anxiety in relation to social anxiety: A review of the literature. KGPS Review: Kwansei Gakuin Policy Studies Review, (12), 1-15.

King, J., \& Smith, L. (2017). Social anxiety and silence in Japan's tertiary foreign language classrooms. In C. Gkonou, M. Daubney, \& J.-M. Dewaele (Eds.), New insights into language anxiety: Theory, research and educational implications (pp. 92-110). Bristol, UK: Multilingual Matters.

Leary, M. R. (1983). Social anxiousness: The construct and its measurement. Journal of Personality Assessment, 47(1), 66-75. Retrieved March 26, 2020 from https://doi.org/10.1207/ s15327752jpa4701_8

Leary, M. R., \& Kowalski, R. M. (1997). Social anxiety. New York, NY: Guilford Press.

MacIntyre, P. D., \& Vincze, L. (2017). Positive and negative emotions underlie motivation for L2 learning. Studies in Second Language Learning and Teaching, 7(1), 61-88.

https://doi.org/10.14746/ssllt.2017.7.1.4

Matsuura, H., Chiba, R., \& Hilderbrandt, P. (2001). Beliefs about learning and teaching communicative English in Japan. JALT Journal, 23(1), 67-82. Retrieved March 26, 2020 from https://jalt-publications.org/sites/default/files/pdf-article/jj-23.1-art4.pdf

McCroskey, J. C., \& Richmond, V. P. (1992). Communication apprehension and small group communication. In R. S. Cathcart, \& L. A. Samovar (Eds.), Small group communication, (4th ed pp. 342-356). Dubuque, IA: William C. Brown.

Mitchell, C. (2017). Language education pressures in Japanese high schools. JALT Shiken, 21(1), $1-11$.

Miyake, K., \& Yamazaki, K. (1995). Self-conscious emotions, child rearing, and child psychopathology in Japanese culture. In J. P. Tangney \& K. W. Fischer (Eds.), Self-conscious emotions (pp. 488-504). New York, NY: Guilford Press.

Okabayashi N. \& Seiwa H. (1992). A study on the reliability and validity of Leary's social anxiety scale. Memoirs of the Faculty of Integrated Arts and Sciences, Hiroshima University, III, Studies in Information and the Behavioral Sciences, 15, 1-9. http://doi.org/10.15027/30258

Reis, H. T., Smith, S. M., Carmichael, C. L., Caprariello, P. A., Tsai, F. F., Rodrigues, A., \& Maniaci, M. R. (2010). Are you happy for me? How sharing positive events with others provides personal and interpersonal benefits. Journal of Personality and Social Psychology, 99(2), 311-329. Retrieved March 26, 2020 from https://doi.org/10.1037/a0018344

Revesz, A. (2012). Coding second language data validly and reliably. In A. Mackey, \& S. M. Gass (Eds.), Research methods in second language acquisition: A practical guide (pp. 203-221). WileyBlackwell.
Swain, M. (2013). The inseparability of cognition and emotion in second language learning. Language Teaching, 46(2), 195-207. Retrieved March 26, 2020 from https://doi.org/10.1017/ S0261444811000486

Woodrow, L. (2006). Anxiety and speaking English as a second language. RELC journal, 37(3), 308 328. Retrieved March 26, 2020 from https://doi.org/10.1177/0033688206071315

Xethakis, L. (2020). The psychometrics of affective, cognitive and social factors impacting group-based learning activities. (Unpublished doctoral dissertation). Kumamoto University, Kumamoto, Japan.

Young, D. J. (1991). Creating a low-anxiety classroom environment: What does language anxiety research suggest?. The Modern Language Journal, 75(4), 426-437. Retrieved March 26, 2020 from https://doi.org/10.1111/j.1540-4781.1991.tb05378.x

Zakahi, W. R., Jordan, F. F., \& Christophel, D. (1993). Social adjustment to college: Communication apprehension and social network development among college students. Communication Research Reports, 10(1), 39-46. Retrieved March 26, 2020 from https://doi. org/10.1080/08824099309359916

Zhou, M. (2016). The roles of social anxiety, autonomy, and learning orientation in second language learning: A structural equation modeling analysis. System, 63, 89-100. Retrieved March 26, 2020 from https://doi.org/10.1016/j.system.2016.09.001 


\section{JALT2020}

COMMUNITIES OF
TEACHERS \& IEARNERS

\section{Appendix A}

The Audience Anxiety Scale (Japanese version: Okabayashi \& Seiwa, 1991) English translations of the Japanese follow in parentheses.

以下の各項目について、あなたは自分にどの程度あてはまると思いますか。最も気持ちに近い箇所 を選しで下さい。 (Please indicate the degree to which each statement below is characteristic or true of you.)

\begin{tabular}{|c|c|c|c|c|}
\hline $\begin{array}{l}\text { 1:全く } \\
\text { その傾向はない } \\
\text { (Not at all } \\
\text { characteristic) }\end{array}$ & $\begin{array}{l}\text { 2:少し } \\
\text { あてはまる } \\
\text { (Slightly } \\
\text { characteristic) }\end{array}$ & $\begin{array}{l}\text { 3:やや } \\
\text { あてはまる } \\
\text { (Moderately } \\
\text { characteristic) }\end{array}$ & $\begin{array}{l}\text { 4:かなり } \\
\text { あてはまる } \\
\text { (Very } \\
\text { characteristic) }\end{array}$ & 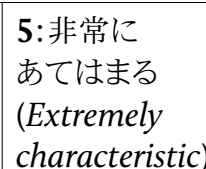 \\
\hline
\end{tabular}

1) 私は人前で話をしている間中、ずっと緊張している。(I usually get nervous when I speak in front of a group.)

2) 私は人前に出て行かなければならない時、緊張する方だ。(I tend to experience 'stage fright' when I must appear before a group.)

3) 私がもし、たくさんの聴衆の前に出て行かなければならないとしたら、 考えただけでも恐い。(I would be terrified if I had to appear before a large audience.

4) 私は人前で話したり、何かをしなければならない時、そわそわして落ち 着かなくなる。(I get 'butterflies' in my stomach when I must speak or perform before others.)

5) カメラで写されることが分かると、緊張してぎこちなくなる。(I would feel awkward and tense if I knew someone was filming me with a movie camera.)

6) 私は人前で話をする時、自分の考えがまとまらなくなってしまう。 $(M y$ thoughts become jumbled when I speak before an audience.)

7) 私は人前で話すことがこんなに苦にならなければいいのにと思う。(I wish I did not get so nervous when I speak in front of a group.)

\section{Follow-up Survey Form}

\section{Appendix B}

English translations of the Japanese follow in parentheses.

前期の調查では、あなたが他者と関わったり、話したりするときにどの程度不安を感じるかについ てお尋ねしました。今回は、英語の講義においてクラスメートと関わったり、話したりする際にどのよ うに感じるかについてお答えください。(In the Spring term you answered some questions about how anxious you feel when talking or interacting with other people. This time, we would like you to answer two questions about how you feel talking and interacting with your classmates in English class.)

1) 私は、入学したときに比べて、英語のクラス中にクラスメートと関わったり話したりすることに対し ての不安感が減った。

(I feel less anxious talking and interacting with my classmates now than I did at the beginning of the year.)

\begin{tabular}{|r|l|l|l|l|l|l|l|}
\hline $\begin{array}{r}\text { 全くそうではない } \\
\text { (I strongly disagree.) }\end{array}$ & 1 & 2 & 3 & 4 & 5 & 6 & $\begin{array}{l}\text { 全くそうである } \\
\text { (I strongly agree. })\end{array}$ \\
\hline
\end{tabular}

2) 上記の答えのようになったのはなぜだと思いますか? (Why do you think so?) 